\title{
Beyond Liberalism: Marxist Feminism, Migrant Sex Work, and Labour Unfreedom
}

\author{
Katie Cruz ${ }^{1}$ (1)
}

Published online: 22 March 2018

(C) The Author(s) 2018

\begin{abstract}
In this article, I use a Marxist feminist methodology to map the organisation of migrant sex workers' socially reproductive paid and unpaid labour in one city and country of arrival, London, UK. I argue that unfree and 'free' (sexual) labour exists on a continuum of capitalist relations of (re)production, which are gendered, racialised, and legal. It is within these relations that various actors implement, and migrant sex workers contest, unfree labour practices not limited to the most extreme forms. My analysis reveals that many migrant sex workers have very limited 'freedom'. This is in stark contrast to the classical liberal claim of sex worker rights activists and academics that the vast majority of migrant sex workers are free, and therefore not coerced, exploited or trafficked. I then consider whether the emerging labour approach to trafficking could help achieve 'freedom' for migrant sex workers. Advocates argue that anti-trafficking efforts must, and can, be refocused on extending minimum labour and social protections to all vulnerable workers. I argue that this approach is disconnected from material interests and history. Rather, migrant sex workers, sex worker rights activists, and all migrant and citizen workers and activists globally must collectively organise against 'labour unfreedom' and hence for meaningful control over their labour and lives.
\end{abstract}

Keywords Coercion · Capitalism · Exploitation · Gender · Law $\cdot$ Migrant sex work $\cdot$ Racialisation $\cdot$ Trafficking $\cdot$ Unfreedom

Katie Cruz

katie.cruz@bristol.ac.uk

1 Law School, University of Bristol, Bristol, UK 


\section{Introduction}

Over the past 25 years increasing concern has been voiced about 'trafficking', routinely described as 'modern day slavery', a worldwide, multimillion pound-a-year industry, run by organised criminals that prey, in particular, on vulnerable women and girls and pose a grave security threat to nation states. Innumerable national, European, and international laws and policies have been written (Dempsey et al. 2012) and countless NGOs and charities have emerged to deal with the problem. At the same time, sex worker rights activists and academics have denounced the anti-trafficking response of nation states, international bodies, and radical feminists (or 'abolitionists'). The argument that anti-trafficking law has proven all but useless in assisting victims and has negatively impacted on migrant sex workers in general is now widespread among both sex worker rights activists and scholars, in the UK and beyond (Agustín 2006, 2007; Bernstein 2010; Doezema 2005; Hill 2011; Gira Grant 2014; NSWP 2011; O'Connell Davidson 2006, 2009; Scoular and O'Neill 2007; SWAN 2015; x:talk project 2010).

This article accepts these critiques and concerns, but questions the use of a classical liberal approach for conceptualising, and responding to, trafficking for sexual exploitation and voluntary migrant sex work by sex worker rights activists and academics. Political economy scholars have criticised liberal constructions of trafficking and Modern Day Slavery for glossing over the substantial unfreedoms that exist in so called free labour and for failing to grasp how the same economic, legal, and political relations create and sustain both unfree and 'free' labour (Kotiswaran 2014; O'Connell Davidson 2009, 2010, 2015; McGrath and Strauss 2015, 2016). The key question now animating many critical studies of trafficking is "whether we should work towards reforming the UN Protocol or [whether] we are better training our energies elsewhere...' (Kotiswaran 2014, 404). While some are attempting to resituate trafficking within a broader critique of precarity or unfreedom that falls short of its threshold (Shamir 2012; Strauss and McGrath 2016; Kotiswaran 2014; Lewis et al. 2014), others insist that we 'stop talking about trafficking' (O'Connell Davidson 2014a). Scholarship that addresses whether and how to understand both migrant sex work and trafficking for sexual exploitation from a critical political economy perspective are, however, in their infancy (Kotiswaran 2014; Strauss and McGrath 2016) and there is currently no scholarship that focuses on the UK. This article applies a Marxist feminist methodology and argues for two reorientations in sex workers rights activism and scholarship.

Sex worker rights activists and academics often use a classical liberal definition of trafficking for sexual exploitation, and so insist that by far the vast majority of sex workers are free workers who have exercised self-determination, migrated or moved voluntarily, work in consensual conditions, and are not exploited. This approach defines coercion and exploitation by reference to individual actions and experiences in the migration and/or labour process. My first argument is that this approach overestimates the amount of freedom that migrant sex workers enjoy. This is demonstrated through a discussion of the broader, macro-social forces and 
relations of unfreedom, within which various actors-'employers', clients, and intermediaries-implement, and migrant sex workers contest, a range of unfree labour practices not limited to the most extreme (such as confinement and physical violence). I therefore propose that unfree and 'free' (sexual) labour exists on a continuum of capitalist relations of (re)production, which are not purely economic; they are gendered, racial, and legal and mediate micro instances and experiences of coercion, abuse, and exploitation in the migratory process, sexual labour process, and lives of migrant sex workers. At one end, 'freedom' signifies the relative ability to control one's labour in favourable working and living conditions. The quotation marks highlight that we can never be fully in control of our labour-our 'living sensuous activity' (Marx and Engels 1968)—within capitalist relations of (re)production (Holmstrom 1977). At the opposite end, unfreedom signifies the inability to control one's labour in favourable working and living conditions.

The extreme end of unfreedom obviously encompasses 'trafficking', defined from a liberal perspective as individual instances of extreme coercion and exploitation. But my approach has the advantage of locating instances of coercion and exploitation within broader macro social forces and relations. It therefore highlights the relationship between the micro practices and macro forces, which must be politically contested because they inhibit migrant sex workers from controlling and commodifying their labour in favourable working and living conditions. My approach also explains why demands for the extension of rights to sex workers will not readily materialise if framed as identity based recognition claims. It is clear that labour 'freedoms' are not going to be handed over easily to (migrant) sex workers and that all workers, citizens and migrants, have an interest in collectively fighting for maximum control of their labour and lives.

I then narrow my focus considerably to reflect on the role of anti-trafficking law and policy for challenging labour unfreedom in migrant sex work. Does anti-trafficking law and policy have a role to play or should we 'stop talking about trafficking'? The human rights approach to anti-trafficking has been criticised for being incapable of challenging the background conditions that create vulnerability to trafficking and other unfree labour practices. Given my focus on labour unfreedoms, the labour approach to trafficking appears highly relevant. In a nutshell, advocates propose that existing moral indignation about trafficking can be reoriented such that nation states will agree that to stop trafficking minimum labour protections must be extended to all vulnerable workers (Kotiswaran 2014; Shamir 2012). My second argument is that the labour approach to trafficking is profoundly disconnected from material interests and history and will not have a significant role in achieving 'freedom' for migrant sex workers. The anti-trafficking agenda now needs to be decentred and viewed narrowly as a criminal law response to unfree labour practices, which is largely in keeping with current policing (Hoyle et al. 2011; Munro 2005; O'Connell Davidson 2006; Crown Prosecution Service 2011). Rather, activists and academics must focus on contesting labour unfreedom by demanding 'freedom' within, and freedom from, capitalist relations of (re)production. This is how migrant sex workers will, alongside citizen workers, and all paid and unpaid workers globally, gain control of their labour and lives. 
In part one, I outline the Marxist feminist methodology that will be used to capture the macro-social forces and micro relations of unfreedom that are obscured by the classical liberal understanding of voluntary migrant sex work and trafficking for sexual exploitation. In part two, I set out the classical liberal feminist definition of trafficking for sexual exploitation and migrant sex work, using examples from empirically informed research with migrant sex workers and my own interview material with sex worker rights activists about organising in London, UK. ${ }^{1}$ In part three, this classical liberal approach is critiqued via an explanation of the organisation of migrant sex workers' socially reproductive paid and unpaid labour in one country and city of arrival, London, UK. In the fourth and final part I argue that the emerging labour approach to trafficking will not play a role in tackling the labour unfreedoms in migrant sex work. Instead, migrant sex workers, sex worker rights activists, and all migrant and citizen workers and activists globally must collectively organise against 'labour unfreedom' and hence for meaningful control over their labour and lives.

\section{Part One: Capitalist Relations of (Re)production: A Marxist Feminist Methodology}

The classical liberal tradition views free wage labour as the consensual exchange of non-exploited labour power between equals in response to market forces. Marxist feminists take a very different approach. The capitalist mode of production relies upon both productive and socially reproductive labour. Our focus is therefore capitalist relations of (re)production (Bryson 2005), which I argue are not purely economic; they are gendered, racialised, and legal. As LeBaron points out, while 'feminist political economy provides a fruitful heuristic frame to investigate unfree labour, few authors within this tradition have focused explicitly on overcoming the binary between free and unfree labour' $(2013,7-8)$. I therefore argue that capitalist relations of (re)production exist on a continuum of unfreedom (see also LeBaron 2015). This approach traces the inner connections between historically dynamic macro social forces - namely capitalist relations of (re)production-and a range of micro instances and mechanisms of control and abuse in the migration and labour process (from the most extreme through to the mundane and routine) to arrive at a

\footnotetext{
1 One piece of activist literature that I engage with was conducted by the x:talk project in (2010) and funded by the Daphne programme (x:talk project 2010). As a member of the x:talk project, I conducted background legal research and presented the report on two occasions in London in 2010 and 2011. This article also draws from interview material with sex worker rights activists in London that I conducted between 2011 and 2012. This research was given ethical approval by the University of Nottingham and funded by the ESRC reference number ES/H014772/1. Thirteen semi-structured interviews were conducted with members of the xtalk collective; Feminist Fightback; General, Municipal, Boilermakers and Allied Trade Union (GMB); International Union of Sex Workers (IUSW); Sex Worker Open University (SWOU); and English Collective of Prostitutes (ECP), and two interviews with sex worker rights supporters from the UK Network of Sex Work Projects. The interviews aimed to explore three themes: the type of rights and freedoms sought; political positions on engaging the state and the law; and the relationship between feminism/s and sex worker rights activism.
} 
broad definition of labour unfreedom. At one end, 'freedom' signifies the relative ability to control one's labour in favourable working and living conditions. At the opposite end, unfreedom signifies the inability to control one's labour in favourable working and living conditions. One final point needs to be noted at the outset. Marxist feminism understands there to be a dialectical relationship between the self (subjectivity and experience) and society (capitalist relations of (re)production). This means that however much certain actors coerce and exploit workers it is imminently possible, and necessary, for workers to act upon these relations in organising for control over their labour and lives.

\section{The Centrality of Labour}

Beginning with our human propensity to labour, the social organisation of labour required to provide for the necessities of life, and our relationship with nature and the environment, capitalism is a historically specific organisation of these relationships. The capitalist mode of production requires that our labour is commodified and sold on the market in return for a wage in what appears to be an equal exchange. However, wage labour is only ever formally free (workers are 'free' to sell their labour power to any buyer but are also compelled to do so in order to survive) and is always exploited (albeit to different degrees) because the production of surplus value, part of which equates to profit, is essential for the reproduction of the capitalist mode of production (Banaji 2003; Brass 1994; Holmstrom 1977; LeBaron 2015; Strauss and Fudge 2013; Strauss and McGrath 2016). Marxist feminists have, however, expanded our understanding of the capital-labour relationship beyond capital's need for labour that produces surplus value. This feminist tradition 'advances the concept of an expanded mode of production, whose essential unity lies in a broad definition of labor', which

incorporates both the value-producing labor associated with the waged economy, and the domestic labor (typically performed by women) required to give birth to, feed and raise the current generation of workers, and the children who will comprise the future workforce (Ferguson 2008, 4) (my italics).

Capitalism, then, needs both productive and socially reproductive labour - the daily and generational reproduction of workers - to ensure its regeneration. The history of capitalism reveals that socially reproductive labour has been sourced in a particular way.

Capitalism separated workers from the means of production, and hence subsistence, via the mechanism of wage labour. But it also separated labour from the family. The sexual division of labour existed in Feudal times, but within the home and community women performed domestic labour, produced goods for sale, and worked the land. With the advent of capitalism women had to engage in waged, productive labour outside of the home and look after their families, deepening the already existing sexual division of labour. These historical shifts explain the equation of socially reproductive labour with the private family form and the unpaid labour of women therein (Conaghan 2017). Socially reproductive labour can be defined narrowly as 
domestic labour or more expansively as 'the labour of individuals to sustain, care for, and attend to the survival of, well-being, and reproduction of themselves and each other' (Hardy 2016). It therefore includes unpaid caring labour in the home, neighbourhood, and community.

This is not a functionalist argument, however. Capitalism could (continue to) commodify socially reproductive labour, potentially making all socially reproductive labour exploited and so productive in the traditional Marxist sense (Holmstrom 1977), or it could replace the family with another institution or source of unpaid socially reproductive labour (Ferguson 2016). The Marxist feminist insight and insistence, then, is to focus on the connections and contradictions between productive and socially reproductive labour, in the home and beyond. As Ferguson and McNally neatly put it:

An adequate theorization of the total social reproduction of the capital-labour relation thus requires a multi-dimensional analysis which, while acknowledging the decisive role of waged-work and other monetized practices, situates these within a nexus of practices through which working-class life is produced and reproduced $(2015,2)$.

This is not a 'new feminist metanarrative or a General Feminist Theory of Everything' (Weeks 2004, 187). Struggles over the social organisation of our labour are not 'the only form of oppression or even the most frequent, consistent, or violent source of social conflict'. But because the social organisation of our labour 'creates the material conditions of existence itself' (Meiksins Wood 2000, 108) capitalist relations of (re)production must be a key focus for scholars and activists.

Three important insights follow. First, capitalist relations of (re)production are not purely economic; these relations are gendered, racialised, and legal. Capitalist relations of (re)production are constitutive of, and constituted by, gender, 'race', and law. Second, capitalist relations of (re)production exist on a continuum of labour unfreedom. Third, capitalist relations of (re)production are constituted by, and constitutive of, agency and experience. 'Capitalism' is not a structure that determines experience. Rather, as history confirms, capitalist relations of (re)production are dynamic and can be reinforced, shaped and altered through organised collective action. I expand on each of these points below.

\section{Gender, 'Race', Law}

Capitalist relations of (re)production are gendered. As outlined above, the capitalist mode of production relies upon productive and socially reproductive labour. Today, women still perform the majority of unpaid socially reproductive labour as well as performing paid labour in ever increasing numbers (Conaghan 2017). Since the 1980s there has been a rise in service based employment and a decline in manufacturing, workers are fragmented as corporations divide up the workforce depending on where the cheapest labour can be secured, wages have declined or stagnated, and union participation has plummeted. Indeed, service based employment is now the dominant form of productive and paid labour in 
overdeveloped capitalist nations, combined with accumulation through financialisation and dispossession (Foster 2010; Harvey 2011). The unpaid socially reproductive labour that women have historically performed, such as care and domestic work, are increasingly paid and understood to be a strong feature of the service economy (Fudge and Owens 2006).

Socially reproductive service based work is, however, often devalued because of its association with 'women's work' and often takes place in private ('the thick walls of the household' (Mezzadri 2016)). On the one hand, its 'unskilled' nature is useful for justifying low wages. On the other, its association with the private sphere of family means that the cost of reproducing labour power can be restricted to the individual wage (Meiksins Wood 2000, 270) and the fact that it takes places in private diminishes the ability of workers to collectively organise and increases the risk of abuse by employers and clients. Under the guise of austerity, many European governments, including the UK, have only worsened this situation. Women in the labour market and with caring responsibilities have been severely affected by continued deregulation of the labour market, reduction of social welfare through cuts to benefits, and eradication of many public services (Busby 2014).

Capitalist relations of (re)production are racialised. As Ferguson points out, along with 'accounting for the sex-gender dimensions of labor, we need also to attend to its socio-spatial aspects ... it's not just what we do to reproduce society, but where we do it that counts in an imperial capitalist world' (2008, 15) (my italics). The spatial location of labouring bodies is based on geo-political imperatives (state boundaries, trade agreements, international treaties, and dispossession and primitive accumulation), the concerted actions of workers to improve their present conditions, and class, gender and 'race' relations between people. Spatially located labouring bodies 'become racialized insofar as they are associated (by skin color, cultural identity, language or accent) with other socio-geographic spaces' (52). A good example is the migration of women to the UK to engage in paid socially reproductive labour. This is a means for reproducing female workers, and often their own families, and is engaged in by women because of prevailing gender relations and attitudes in countries of origin and the UK. Migrant women workers in the UK become racialised when they are associated with 'other socio-geographic spaces'. Racialisation of migrant women occurs when their cultural practices become associated through media or legal discourse, for example, with current social, economic and political meanings of their country of origin. Their 'other' status is then justification for their devaluation, segregation, and exclusion (Farris 2015; Ferguson 2016, 53).

Capitalist relations of (re)production are legal. Political economy scholars use the term 'hyper-precarity' to mark the effect of neoliberal labour markets, 'migration trajectories', and highly restrictive immigration regimes on the working conditions of migrant workers, asylum seekers, and refugees (Lewis et al. 2014). Hyper-precarity, then, is an effect of exclusion from, and/or 'adverse incorporation' within (Phillips 2013, see also Brass on 'deproletarianization' 1994), employment and immigration regimes in the UK, which, combined with certain 'push' factors, leave workers with few options (Lewis et al. 2014; see also Fudge 2013; Strauss and McGrath 2016). In this context, migrants will often enter 'the labour market at the lowest possible point in their effort to secure work' (Lewis et al. 2014, 13). Marxist and social 
reproduction feminists more explicitly stress the legal dimensions of capitalist relations of (re)production. For example, Ferguson reminds us that

interests and relational dynamics can and do compete with the capitalist imperative. Struggles for access to abortion, childcare, better wages, and healthy drinking water, for example, reshape relations between workers and capital, and those among workers themselves. If successful, they chip away at patriarchal and other forms of relations; if they fail, they tend to reinforce such relations $(2016,52)$.

\section{A Continuum of Labour Unfreedom}

These insights inform a broad definition of labour unfreedom that centres on capitalist relations of (re)production. These macro forces mediate micro relations of coercion, abuse, and exploitation in the migration and labour process, and in the lives of migrants more generally. Whereas the classical liberal approach defines unfree labour as extreme instances of coercion and abuse at the micro level of the workplace, this Marxist feminist approach traces the connections between a whole range of troubling workplace practices and experiences that are constituted by, and constitutive of, broader macro forces and relations (see also LeBaron 2015; Strauss 2012). In contrast to the classical liberal tradition, then, unfreedom is not incidental to capitalism (Banaji 2003). At one end of the continuum is 'free' labour; the quotation marks signalling that freedom within capitalist social relations cannot exist because we cannot reproduce families, communities, and ourselves without access to a wage. 'Free' labour, then, is characterised by the limitation of labour unfreedom. ${ }^{2}$ It exists where waged and unwaged labour is embedded in a system of labour and social rights and protections. Characterising 'free' wage labour as present where labour unfreedoms are limited is complimentary to McGrath's and Strauss's definition of workers' 'freedom' - 'freedom of movement, freedom to change employers, and freedom to contest conditions' - as the opposite of unfreedom (2015). Unwaged labour protections include, for example, access to childcare, eldercare, abortion, healthcare, and affordable housing and food. At the same time, Marxist feminists insist that freedom will entail ending the capital-labour relation (and hence all forms of labour exploitation and alienation) such that we can have meaningful collective control of our labour and lives (see, for example, Federici 2011; Ferguson 2016; Meiksins Wood 2000; Weeks 2007, 2011).

\footnotetext{
${ }^{2}$ The line between 'freedom' and unfreedom is a historical and political decision or judgement. See O'Connell Davidson, who defines 'Modern Slavery' as 'not a thing, but a set of judgments and contentions about political authority, belonging, rights and obligations, about commodification, market and society, about what it means to be a person, and what it means to be free. As such it should be a zone of political contestation ...' $(2015,207)$.
} 


\section{Subjectivity and Experience}

Marxist feminists do not privilege 'structure' over 'agency', 'experience' or 'consciousness' and would reject any such approach as un-dialectical. Rather, our task is 'to capture the dialectical interplay between the subjective and the social and thereby make clear the ways in which distinct experiences or subjectivities are part of the same, over-arching set of social relations' (Ferguson 2008, 48; see also Weeks 2007) (my italics). We therefore need to understand experiences of labour and labour practices as part of broader, dynamic social relations. This means paying attention to the subjective experiences of workers and mapping how they are constitutive of, and constituted by, historically dynamic capitalist relations of (re) production, which are gendered, racialised, and legal (see Weeks 2004; Ferguson and McNally 2015 for excellent examples). This approach has the advantage of recognising 'the determined dimension of social life while simultaneously affirming the creative force of the subjective will' (Weeks 2004, 187). In other words, it recognises that because everyday labour relationships are constitutive of, and are constituted by, capitalist relations of (re)production it is immanently possible for workers to collectively contest these very same relations.

Marxist feminists are therefore committed to condemning a broad range of labour unfreedoms that both capitalists and classical liberal thinkers have at best failed to grapple with, and at worst consciously obfuscated or ignored. Scholarship that addresses whether and how to understand trafficking for sexual exploitation and migrant sex work from a labour unfreedom perspective are, however, in their infancy (Kotiswaran 2014; Strauss and McGrath 2016) and there is currently no scholarship that focuses on the UK. In part two I outline the classical liberal approach that is applied by sex workers rights activists and academics to define voluntary migrant sex work and trafficking for sexual exploitation.

\section{Part Two: Liberal Feminism, Migrant Sex Work and Trafficking}

The minimal requirements of a liberal feminist theory of justice are a commitment to uphold an individual's capacity to exercise self-determination, autonomy, and choice and for these core values to be ensured by certain constitutional arrangements, including the rule of law and human rights (Baehr 2017). In classical liberal feminism this tends to yield a focus on the removal of coercive interference with a woman's person and her ability to acquire, control, and exchange property, including property in her person (Dickenson 1997). Coercion is defined as forcible or fraudulent interference with a woman's person or property by the state, market, or any other actor, and its absence is ensured by the legal protection of rights (Baehr 2017). Many sex work scholars and activists deploy this classical liberal feminist framework to argue that when subject to physical coercion and exploitation, sex workers are slaves, but otherwise they voluntarily contract to sell their detachable bodily property (Cavalieri 2011). The focus on certain interpersonal means-physical force, violence or its threat, and deception-in combination with specific purposes-exploitation-operates to draw the line between trafficking (unfree labour) 
and free migrant sex work (or free wage labour) (Adams 2003; Agustín 2006; Ditmore 2008; Doezema 2005; NSWP 2011; Mai 2009; Murray 2001).

The classical liberal feminist approach to sex work and trafficking has been criticised for assessing societal force and oppression solely through the lens of individual experience (Cavalieri 2011) and for defining coercion and exploitation narrowly (Larson 2004; O'Connell Davidson 2014b). While not commonly deployed in the context of sex work debates, and while still attached to an assessment of coercion through the lens of the individual, there do exist liberal feminist theories that focus on forms of interference that threaten the autonomy of the individual beyond that which feature in classical liberal feminism (see, for example, Clough 2015; Mackenzie 2014). Specifically in the context of sex work, Nussbaum endorses a contractual model for the exchange of sexual capacities that should operate absent physical force and fraud, as well as poverty and stigmatisation (1998).

A corollary of the classical liberal feminist sex work position is that migration for sex work and trafficking for sexual exploitation cannot, and should not, be conflated. This argument is marshalled to contest various panics about sexual slavery, migration flows, and organised crime. The dangerous, and seemingly near global liaison of radical feminist abolitionists and (inter)national institutions determined to stamp out trafficking for sexual exploitation has been much explored (Bernstein 2010; Halley et al. 2006; Scoular and O'Neill 2007). The x:talk project and English Collective of Prostitutes are grassroots sex worker rights networks in London that have been vocal about the confluence of abolitionism, immigration control, and criminalisation of sex work. The x:talk project argue that prominent female labour politicians advocating abolition 'have dominated the debate for at least the past ten years and this has driven much of the design of ATP [anti-trafficking policy] in the UK' (2010, 7). Similarly, referring to the then recently defeated Labour government, the ECP are critical of the 'so-called feminists within government' who pursued a 'law and order, pro-criminalisation, pro-repression' agenda to sex work and trafficking (ECP activist).

The radical feminist, or 'abolitionist', perspective that is being criticised views prostitution and trafficking as forms of sexual expropriation and exploitation rooted in sex inequality (MacKinnon 1989, 2010) or patriarchal structural inequality (Dempsey 2010). In the context of prostitution and trafficking, radical feminists view both as indistinguishable practices of sexual slavery wherein the mind and body is commodified. Prostitution, trafficking, slavery, and rape are described as equivalent, women are depicted as objects and passive sexual slaves, and the criminal justice system is the prioritised arena for developing an oppositional consciousness (Barry 1995; MacKinnon 2011; Raymond 2004; Jeffreys 2009). Again, however, this perspective is somewhat at odds with more nuanced radical feminist theorising, as exemplified in MacKinnon's own work. Writing against the liberal view that forced sex can be easily isolated from consensual sex, MacKinnon describes sexuality as 'a pervasive dimension of social life, one that permeates the whole, a dimension along which gender occurs and through which gender is socially constituted; 
it is a dimension along which other social divisions, like race and class, partly play themselves out' (1989, 130). For MacKinnon, the eroticisation of domination and submission defines masculinity and femininity respectively and takes the form of a spectrum of sexual restriction and coercion, from norms of female servility to rape. She then insists that sexual domination be chipped away at by its dialectical other; consciousness raising in activism, scholarship, and state and legal institutions (1989, 2010). ${ }^{3}$

Nevertheless, in the context of sex work/prostitution and trafficking activism and scholarship the less nuanced expression of radical feminism dominates and is being countered with a classical expression of liberal feminism, which views the clear majority of migrant sex workers as free, voluntary workers.

\section{Sex Work and Unfree/Free Labour}

A good example of this argument in the UK context comes from sociologist Nick Mai. On the basis of 100 interviews with migrant sex workers in London, Mai's research documents 'the links between migration and the UK sex industry' (2009, 4 ). The central conclusion of the study is that only a very small minority of migrant sex workers interviewed (13\%) were economically and/or sexually exploited in the workplace and/or migration process in situations wherein there was no consent, through to relatively more consensual arrangements $(2009,4,32)$. In short, the vast majority of interviewees (87\%) are marked off as free migrant sex workers.

A clear line is therefore presumed to exist 'between exploitative and non-exploitative practices in the sex industry' $(2009,32)$. Mai relies on interviewees' use of the word 'exploitation' in the context of sexual violence or severe economic exploitation, including debt bondage. Of the $13 \%$ of exploited workers only $6 \%$ 'felt that they had been deceived and forced into selling sex in circumstances within which they had no share of control or consent' (4). Force and coercion are defined as physical threats, confinement and isolation, and removal of passports (39). The remainder of the $13 \%$ were engaged in 'relatively more consensual arrangements' (32). For example, 'interviewees were aware that they would be selling sex, but not of the exploitative working conditions that they were required to endure' (32). This suggests that $87 \%$ of migrant sex workers interviewed were free subjects, who freely and consensually decided to migrate, freely consented to their workplace conditions, and experienced no coercion, force, abuse or exploitation in the workplace.

The x:talk project endorse Mai's findings and maintain that migrant sex work and trafficking are separate categories, to be distinguished using the concepts of 'force', 'consent', and 'exploitation' (2010, 3, 21, 36). This is also the position of the ECP, who argue that 'trafficking legislation should be refocused so that it does distinguish between situations where there is force, coercion, and what it currently is, which is anti-immigration law' (ECP activist). A human rights-based response is

\footnotetext{
3 In future analyses of sex work and trafficking it would be fruitful to bring into conversation Marxist feminist theories of capitalist formation and radical feminist theories of the heterosexist formation to consider overlapping labour and sexual unfreedoms.
} 
then advocated for voluntary migrant sex workers and trafficked victims, combined with the criminalisation of trafficking. While not always evidenced through empirical data, this definition of consent and exploitation marks the threshold of unfree/ free migrant sex work for many activists, NGOs, and academics (see, for example, GAATW 2010; NSWP 2011; Bindman and Doezema 1997; Doezema 2005).

Given the historical exclusion of (migrant) sex workers from those who enjoy self-ownership, it is unsurprising that the commodification of bodily property and self-determination have taken centre stage. Resort to this classical liberal position also reflects the pressing need to circumvent radical feminism with an equally forceful narrative. But the classical liberal feminist approach is equally reductive; it overestimates the amount of 'freedom' that migrant sex workers enjoy because it fails to provide an account of the broader, macro forces and relations of unfreedom within which 'employers', clients, and intermediaries implement, and migrant sex workers contest, a range of unfree labour practices not limited to the most extreme forms. In the third part, I use a Marxist feminist methodology to bring into focus the macro social forces and micro relations of unfreedom that are obscured by the classical liberal understanding of voluntary migrant sex work and trafficking for sexual exploitation.

\section{Part Three: Migrant Sex Work and Capitalist Relations of Re/ production: London}

Sex work is a good example of labour that troubles the productive-paid/unproductive-unpaid separation of labour that is particular to capitalism and liberalism. Sex work is the commodification or monetisation of socially reproductive labour, or more succinctly, paid social reproduction. Sex workers also socially reproduce their families and communities. Sex workers also engage in unpaid social reproduction. In this part, I map the capitalist organisation of migrant sex workers' socially reproductive paid and unpaid labour. I pay attention to how capitalist relations of (re) production are gendered, racialised and legal, and how these broader social forces mediate micro relations of coercion, abuse, and exploitation in the labour process and in the lives of migrant sex workers more generally. While space constraints prohibit me from completing a macro analysis of capitalist relations of (re)production in migrant sex workers' countries of origin and country of arrival, I do pinpoint this broader geo-political scene where its inclusion would be particularly illuminating in future empirically informed, transnational, Marxist feminist research about migrant sex work. Having done this, I argue migrant sex workers have very limited 'freedom'. To capture the dialectical interplay between social forces and subjectivity or experience, I highlight activist's demands for rights and argue that these 'freedoms' have the best chance of success if migrant (sex) workers and citizens collectively fight for maximum control of our labour and lives. I end this part by pointing to promising instances of sex worker organising that are challenging capitalist relations of (re)production by engaging in collective anti-capitalist, anti-racist, and anti-sexist struggles. 


\section{Migrant Sex Work: Paid Social Reproduction}

The service sector has grown in response to deindustrialisation and is now the dominant mode of productive capital accumulation in many Western states, including the UK. The service sector is characterised by post-industrial waged or monetised labour, including teaching, call centres, care work, leisure and nighttime entertainment, and sexual commerce. As a major source of capital accumulation, the sex industry is now extremely diverse and its success has been, and continues to be, shaped by technological transformations and postmodern sexual attitudes (Bernstein 2007). What, then, do migrant women receive in exchange for their sexual labour power in London's sex industry? Is it an 'equal exchange'?

Managed sex work in the UK includes, but is not limited to, illegal brothels and legal erotic dance venues. The worker sells her labour power, which the capitalist combines with essentials for production, including rent, machinery, and technologies. During her time at work she produces commodities-which can be a product or a service (Marx 1977; Gough 1972; Tregenna 2011)—which must be greater in value than what the capitalist has spent on her labour power and other essentials. Without receiving this greater value the capitalist would not make a profit. This means that the wage received by a sex worker will never be equal to what she has produced because that would make the whole process pointless for the capitalist. It is the value created for the capitalist for which a sex worker is not paid that is an 'exact expression' of her exploitation by capital (Marx 1867, 1990, 326).

Workers in brothels and erotic dance venues are nominally self-employed and experience high levels of financial extraction, including house fees, commission, fines, and "tip outs" to their house mum or security (Cruz 2013; O'Connell Davidson 1998, 2014b; Hardy and Sanders 2014; Cruz et al. 2017). The capitalist buys her labour power plus the means of production, so rents a building, installs poles and various payment and security technologies, and the dancer produces the service. However, she produces a single service that is immediately consumed by the customer. She does not produce tangible products—-such as iPhones-that the capitalist can then sell on to create a profit. Nor can the capitalist introduce machinery to speed up production or replace dancers with robots-at least not yet. He also needs to keep the commodity service affordable in a competitive market. Hence he must organise production and consumption of the commodity service in such a way that he is able to pump out surplus labour and make a profit. This is done by setting the price of commodity service, stipulating multiple levels of financial extraction for each dance, introducing competition in the production process, and extending the working day, all of which will leave him with greater value than what he has put into the process. These practices are used across the sexual labour market, including prostitution (regardless of its legality) and erotic dance (Cruz 2013; O'Connell Davidson 1998, 2009; Hardy and Sanders 2012; Cruz et al. 2017). Female migrant workers therefore provide 'employers' with cheap, unprotected, and dependent labour power, which can be disciplined and expelled as and when deemed necessary. And if it is correct that practically all sex workers working as prostitutes in London are migrants (ACPO 2010), it is likely that demand for the cheapest and 
most disposable female labour trumps any demand by consumers for specific access to migrant women.

What about self-employed migrant sex workers? Their labour is not commodified and so exploited, but it is a 'monetized activity'. As Ferguson and McNally remind us, 'while wage-labour is the principal means of subsistence for the dispossessed, activities such as street-vending, selling sex and independent domestic production are also part of the social picture' $(2015,2)$. Self-employed migrant sex workers are independent commodity producers, engaged in the independent production of sexual services wherein she is compelled to appropriate or exploit her own surplus labour. This means that the independent sex worker is 'self-appropriating' or 'self-exploiting' (see O'Connell Davidson 2006; Kotiswaran 2014) when she earns more than she needs to reproduce herself and her family; when she is able to earn money over and above her subsistence and, for example, invest in her business, rent a property for work, buy the services of a receptionist, or security staff.

On the one hand, this could obviously be very empowering. But it also entails maintaining a competitive edge, which might mean, for example, working longer hours and providing niche services that are less favoured by the worker. This is a broad category of migrant sex workers, covering those struggling to set up their business through to very successful self-employed migrant sex workers. As a worker, she has interests in common with all workers; as owner of means of production, however, she has interests in common with capitalists. In other words, these migrant sex workers have a divided allegiance towards the two decisive classes in capitalist society. Bringing Marx's analysis of the independent commodity producer up to date, then, the 'self-exploiting' migrant sex worker 'is cut up into two persons'. As owner of the means of production she is a capitalist. And as a worker she is her own wage-worker (Marx 1956, 1977, 397).

However, it is likely that many self-employed migrant sex workers in London will not be 'self appropriating' any of their surplus labour; they will not be setting up their own business in London. Rather, they will be selling sexual services in order to cover their basic subsistence in what is a highly transient industry (Mai 2009; Hardy and Sanders 2015). However, whether a migrant sex worker is exploited, 'self-appropriating', or simply making enough money to cover her subsistence, what is common to all these processes as they occur within capitalist relations of (re)production is the compulsion to earn wages or engage in monetised activities in order to access subsistence (Denning 2010).

Labour law is rarely directly involved in the commodification of sexual services. Migrant sex workers who work in managed environments experience 'employment precarity' (Fudge 2013, 99); the dominant employment relation is false selfemployment, and so workers have no certainty of employment, little control over the labour process, no regulatory protection, and, while wages can be adequate there is no certainty that a debt relationship between the worker and management will not emerge (Cruz 2013; Cruz et al. 2017). Unless migrant sex workers register as self-employed they will not be able to access many social welfare protections that depend on being in paid employment. Nominal self-employment in the sex industry could be viewed as a particular example of the general trend towards casualisation, often in the service sector, that labour law has notoriously struggled to bring under its auspices (Cruz 2013; Fudge and Owens 2006). But sex workers have never had 
and lost (labour) rights. It is therefore more instructive to see the organisation of paid social reproduction (and indeed paid labour in general) emulating the precarious conditions that have always prevailed for sex workers.

Considering migrant sex work as a form of paid social reproduction engaged in by women sheds light on abuse in the workplace and the absence of employment protections. As a form of work that often takes place in the 'private' sphere (the 'thick walls' of the home, apartment or brothel) it is not seen as 'real' work by the employers, clients or the state. The relationship between sexism, the desire to control female sexuality, and the stigmatisation of sex workers also helps to explain on-going criminalisation and reluctance to see sex work as a legitimate form of service work (Nussbaum 1998). This mix of invisibility, devaluation, criminalisation, and state disavowal all combine to allow managers and clients to practice high levels of exploitation, control, and abuse. Migrant sex workers are therefore part of a particularly vulnerable and precarious workforce. Racialisation deepens their insecurity and the potential for abuse through 'othering', a process within which immigration rules are deeply enmeshed.

The UK immigration regime is restrictive and punitive for low skilled workers and only 'highly valued migrants' (entrepreneurs, investors, and those who are 'exceptionally talented') from outside the EEA can enter without a job. In order to reside legally, migrants moving from countries outside the EEA will need to enter the UK on a student or other temporary visa (such as a Visitor visa if coming from a 'Visa National' country). Illegal clandestine entry is the only other possibility. But restrictions on entry are not limited to non-EEA workers. Like A8 and A2 nationals $^{4}$ previously, Croatian nationals can move freely into self-employment but must otherwise be sponsored by an employer. The visa, or lack thereof, will then impact their position in the labour market. Those who move from non-EEA countries will be restricted to sections of the labour market that illegally 'employ' workers, such as sex work. Croatian workers are restricted to self-employed sectors, like the sex industry, and while restrictions have now been lifted on labour market access for A8 and A2 workers, employment relations and immigration patterns do not necessarily change with legislation (Anderson 2010, 309). Despite a formal legal change to labour market access, then, it is possible that the nominal self-employment of A8 and A2 nationals in the sex industry will continue (see Hardy and Sanders 2014, 92).

And whether residing illegally or legally, migrant sex workers face two further layers of institutionalised hostility and uncertainty: restricted access to public funds and essential services and the threat of removal or deportation for immigration and/ or sex work related offences. Workers from outside the EEA are normally prohibited from accessing public funds. ${ }^{5}$ Home Office and Local Authority support for migrants with illegal status relies upon proof of humanitarian or care needs and is both complex and diminishing. ${ }^{6}$ Non-EEA migrants with illegal status can be evicted from private accommodation, are prohibited from renting property, and cannot open a bank account. ${ }^{7}$ Clandestine entry, overstaying or failing to observe a visa

\footnotetext{
${ }^{4}$ Nationals from countries that joined the European Union in 2004 and 2007.

5 Section 115 of the Immigration Act 1999.

6 Part 1 of the Care Act 2014, Section 66 and Schedule 11 of the Immigration Act 2016.

7 Section 20-21 of the Immigration Act 2014, Sections 39-42, 45 of the Immigration Act 2016.
} 
condition (for example, working without authorisation) can result in detention and administrative removal. ${ }^{8}$ Prosecution is possible in many cases, including entering without leave and knowingly overstaying, ${ }^{9}$ and it is now a criminal offence to work without authorisation ${ }^{10}$ and wages can be seized under the Proceeds of Crime Act 2002. The UK Borders Act 2007 makes deportation compulsory for any person over 17 sentenced to more than 12 months in prison. Offences related to the sex industry, such as brothel keeping or controlling for gain, would therefore see migrant sex workers deported. Following on from a police raid of a brothel or club a non-EEA migrant sex worker, if she is not deemed potentially trafficked, and does not have a visa or has overstayed, will be removed at best, prosecuted at worst.

EEA migrant workers in the sex industry also face institutionalised uncertainty. While it is possible to reside and access public funds for 3 months, EEA nationals can be removed after this period for not exercising a treaty right. ${ }^{11}$ A Freedom of Information request that I submitted to the Home Office in 2013 revealed that 1675 EEA nationals had been served with notice and 1135 removed between 2006 and 2012 for failure to exercise a treaty right, with Romanian nationals by far the most affected (425 removals). ${ }^{12}$ It is not possible to know how many migrant sex workers have been threatened with, or actually removed, using these powers, but the ECP has recently reported that Romanian sex workers are being served with notices of removal. ${ }^{13}$ Any practice of targeting and removing EEA sex workers for failure to exercise a treaty right is, however, unlawful. The Court of Justice of the European Union has ruled that if a member state allows its own citizens to work as self-employed sex workers it must recognise self-employed sex workers from EEA countries as exercising a treaty right. ${ }^{14}$ Nonetheless, given the criminalised nature of sex work it is possible that EEA migrant sex workers could be deported following conviction of an offence on the grounds of public policy, security, or health. ${ }^{15}$

Immigration law (in combination with absent labour protections) therefore sets limits on a migrant workers' ability to commodify her labour power, restricting her access to sectors willing to employ 'illegal' workers or by forcing her into self-employment. Immigration law also threatens arrest, detention, and removal and severely restricts access to public funds. We also know that migrant sex workers are experiencing heightened policing of their workplaces as a result of anti-trafficking law and policy and that the threat of arrest and deportation looms large (Mai 2009; x:talk 2010).

\footnotetext{
8 Section 5 of the Immigration Act 1971.

9 Section 24 of the Immigration Act 1971.

10 Section 34 of the Immigration Act 2016.

11 Regulation 23 and 26 of the Immigration (European Economic Area) Regulations 2016.

12 On file with author.

13 'Romanian sex workers challenge UK immigration policy' (2016) The Guardian 1 May. Available at: https://www.theguardian.com/uk-news/2016/may/01/romanian-sex-workers-challenge-uk-immigratio n-policy. Accessed 2 February 2018.

14 Case 268/99 Jany v Staatssecretaris van Justitie [2001] ECR I-8615.

15 Regulation 27 of the Immigration (European Economic Area) Regulations 2016.
} 
Attending to the spatial location of capital-labour tells us that migrant sex workers purposefully choose to enter the UK, acting upon broader geo-political forces. Ferguson and McNally argue that the neoliberal era has been marked by the 'globalization of primitive accumulation. Unrelenting, large-scale processes of dispossession have dramatically swelled the size of the global labour reserve, while also rendering it more international than ever before' $(2015,9)$. Dispossession occurs by turning public assets into private goods that can then be used to make a profit. Indeed, a cursory glance at Brazil's recent history, from where it is reported a sizable portion of migrant sex workers in London have moved in recent years (ACPO 2010, 50; ECP activist), reveals that the 1990s marked a decisive shift from an economy based on import substitution industrialisation to neoliberal economic policies. The 'Washington Consenus' model was implemented, opening the economy to foreign investment, trade liberalisation and market interest rates and by privatising state services and companies, as mandated by the IMF and World Bank (Mollo and SaadFilho 2002). The UK state is responding to, and is part of, this global geo-political scene. Future research into the migration of women into the UK sex industry should trace 'the global dynamics that significantly drive 'national' policies regulating labour markets, immigration, education and so on' (Ferguson and McNally 2015, 3). The more modest point I am making is that UK immigration law has 'repressively incorporated' (9) migrant sex workers and so participates in their 'othering' by associating their labour 'with other socio-geographic spaces' (Ferguson 2016, 52). Migrant sex workers do not arrive with a visa to work in the sex industry; they are not tied to an employer. Rather, the differentiated exclusion of migrant sex workers and heightened policing through a combination of immigration law, anti-trafficking law, and absent labour protections associates migrant sex workers with 'other' jurisdictions and spaces. They are rendered criminals, second-class citizens in a host of ways that do not necessarily turn on having illegal status. At the same time, the UK state refuses any connection with the 'other' spaces from which migrant sex workers move.

This legal 'othering' occurs, and is reinforced by, media discourses and prevailing gender and racial stereotypes about (migrant) sex workers in the UK. This mix of law, popular discourse, and stereotypes creates a powerful image of migrant sex workers that serves to justify their devaluation and abuse by the UK state, employers and clients and creates a need for unregulated labour intermediaries (Strauss and Fudge 2013) who are also able, should they wish, to abuse, exploit, and coerce migrant sex workers without oversight. While the threat of criminalisation for recruiting or 'employing' migrant sex workers may act as a deterrent, it clearly will not alter the capitalist relations of (re)production (including legal relations) that produces this highly vulnerable workforce.

\section{Migrant Sex Work: Unpaid Social Reproduction}

What, then, are the connections between the paid social reproduction of migrant sex workers and their unpaid social reproduction? The situation of female citizen workers with caring obligations has worsened in recent years. But (migrant) 
sex workers had no protections to lose; they had no labour rights or guaranteed access to benefits and public services. The organisation of unpaid, gendered social reproduction, such as caring for children, is therefore increasingly emulating the conditions that have always prevailed for (migrant) sex workers. Indeed, it is now the case that the paid labour of female workers must 'pay' for social reproduction, such as childcare. These are conditions that (migrant) sex workers are all too familiar with.

Migrant sex workers subsidise 'employers' and the state. In other words, sex work functions as a 'kind of alternative 'welfare' system' (O'Connell Davidson 1998, 193) where the state and employers provide little or no help with unpaid social reproduction (such as housing or childcare) and opportunities for secure and well-protected jobs (see also Hardy 2016). Second, female migrant workers subsidise social reproduction in their country of origin through wage remittances. Wage remittances worldwide tripled between 2002 and 2012 and female migrants have been sending more than their male counterparts (Ferguson and McNally 2015, 11). We have no data on remittances being sent from the UK by migrant sex workers. However, if it is indeed true that practically all sex workers in London are migrants it is highly likely that wages remittances are being sent to other countries that do not provide sufficiently for social reproduction. At the same time, responsibility for social reproduction, in the UK or otherwise, will obviously act as a pressure to maximise earnings and so could lead migrant sex workers to accept conditions that would otherwise be refused.

Sex work activists and academics do highlight the poor working and living conditions of migrant sex workers, often focusing on the most extreme practices of coercion and exploitation. They also mention the restrictions and exclusions of certain laws, including immigration laws. However, I have argued that broader social forces, namely capitalist relations of (re)production, must be viewed as mediating a whole array of troubling micro practices carried out by management, clients, and the state-for example, extensive control of the labour process, including the price of the commodity service, multiple levels of financial extraction, extension of the working day, physical abuse, intimidation, and threats, and lack of investment in social reproduction. If 'free' labour exists where paid and unpaid labour is embedded in a system of labour and social rights and protections, we must conclude that the vast majority of migrant sex workers populate the extreme end of unfreedom. However, Marxist feminism insists on a dialectical interplay between social forces and subjectivity or consciousness. We therefore need to ask: How are migrant sex workers and activists acting upon these social forces to ensure some measure of 'freedom'? What demands could ensure more 'freedom' for migrant sex workers?

\section{Migrant Sex Work and Labour Un/Freedom}

Sex workers, activists, and academics are discussing and demanding labour 'freedoms'. They are arguing for individual and collective labour rights in combination with regulation of labour intermediaries, recruitment agencies and brothels/clubs, 
decriminalisation, social welfare entitlement, and radical restructuring of border controls in recognition that these 'freedoms' will transfer a significant amount of power to (migrant) sex workers (Mai 2009; x:talk 2010; Cruz 2013). A commitment to human rights norms is also found in sex worker rights activism. For example, the $\mathrm{x}$ :talk project emphasise key human rights obligations, including the UN Convention on the Protection of the Rights of All Migrant Workers and Members of their Families and the ILO Convention no. 143: Convention on Migrant Workers. These conventions are cited in support of fair treatment in the workplace and access to employment and social security protections, regardless of migration status (x:talk 2010).

But migrant sex workers have not achieved anything close to 'freedom'. Sex workers are not attaining the rights assumed to be afforded to all citizen workers. Rather, the conditions of paid workers are diminishing and increasingly resembling those characteristic of sex work (O'Connell Davidson 2014b). This is because the social welfare contract that was successfully won in the middle of the twentieth century, and provided some measure of decommodification for workers, has been buckling under the weight of postindustrial transformations for some time now (Conaghan 2017; O'Connell Davidson 2014b). And the diminishing protections for unpaid socially reproductive labour that female citizen workers are confronted with are a struggle that (migrant) sex workers are all too familiar. As McNally and Ferguson remind us, capitalism must commodify labour power and has no built in mechanism for looking after workers; 'the drive to accumulate puts continual pressure to deny the (costly) humanity of real people, to deny the 'excess' needs thrown up by socially embodied human life and to impose 'bare life' instead' $(2015,17)$. Capitalist relations of (re)production are therefore most effectively (re)constituted by cheap and 'othered' paid labour and unpaid socially reproductive labour that is the responsibility of individuals or families. The paid and unpaid sexually reproductive labour of migrant (sex) workers fits this ideal. It is therefore clear that labour 'freedoms' are not going to be handed over easily to (migrant) sex workers and that all workers, citizens and migrants, have an interest in collectively fighting for maximum control of their labour and lives.

In this part, I have argued that sex worker rights activists and academic studies need to abandon the classical liberal unfree-free binary and replace it with dialectical studies of the interplay between capitalist relations of (re)production and workers struggles against labour unfreedom. This Marxist feminist approach reveals the array of labour unfreedoms within which migrant sex workers must, and do, act to improve their lives. But it also explains why the straightforward demands for inclusion and recognition that feature heavily in much activism and scholarship are not enough. In conclusion, then, it is important to point to instances of sex work activism that challenge capitalist relations of (re)production. The English Collective of Prostitutes and the x:talk project situate sex work within an understanding of how migrants, and those who are homeless, poor or otherwise disenfranchised lack control over their labour and lives. They therefore campaign and organise alongside other activists, for adequate state provision for social reproduction, for access to education, healthcare and housing, and against borders. At the same time, working class political organisations, including trade unions, must be more inclusive of the 
struggles of (migrant) sex workers ${ }^{16}$ and have much to learn about how to challenge labour unfreedom beyond the workplace.

In the final part I narrow my focus. I ask whether emerging labour approaches to anti-trafficking law and policy could 'chip away at' (Ferguson 2016, 57) capitalist relations of (re)production by securing some measure of labour 'freedom' migrant sex workers.

\section{Part Four: The Anti-trafficking Labour Paradigm: Contesting Unfreedoms?}

Sex worker rights activists and academics that use a classical liberal approach argue that trafficking could be more effectively dealt by a combination of human rights for voluntary migrant sex workers and a victim centred rights agenda for victims of trafficking. This approach would blend appropriate (as opposed to over) enforcement of criminal laws against trafficking with protections for those who wish to remain in, or leave, the UK, including automatic granting of refugee status, long term victim support, and removing requirement of police co-operation in criminal investigations (Mai 2009). Protection and assistance of trafficking victims is contained in the UN Protocol in non-obligatory terms and has been a major focus of NGOs across the globe.

Many academics and activists critical of the abolitionist and criminalisation/ border control approach to trafficking champion the human rights agenda (see, for example, Gallagher 2009; Milivojevic and Pickering 2013, 597) and jurisprudence for highlighting, and challenging, the facilitating role of the state in Article 4 abuses, which includes trafficking (Mantouvalou 2010; see Mantouvalou's body of work in general for an excellent example of this approach). However, the human rights agenda has been criticised for being a reactive response to individual instances of coercion and exploitation. It fails to deal with the root causes of trafficking and deals with workers as victims and with 'employers' as individual bad apples to be criminalised (Shamir 2012; Kotiswaran 2014). Human rights case law does, however, confirm the state's role in violations of Article 4. This body of case law tells us that member states have a positive obligation to take substantive measures to prevent slavery, forced labour, and trafficking, and the European Court of Human Rights has stipulated that member states enact criminal laws and immigration rules that discourage trafficking. ${ }^{17}$ Given that repressive criminal and border rules taint the history of anti-trafficking law and policy we must question whether laws enacted pursuant to this positive obligation will depart from this rationale by, for example, providing migrant sex workers with permits to work in the UK unattached to any particular employer. It seems unlikely.

\footnotetext{
16 ASLEF, GMB and UCU have all passed motions supporting the collective organization of sex workers and decriminalization to encourage organization and promote safety. In 2017 the TUC voted against this motion. Buchan, Lizzy. 2017. TUC leaders reject call to decriminalise prostitution. The Independent. 13 September. http://www.independent.co.uk/news/uk/politics/tuc-leaders-prostitution-decriminalise-rejec t-call-trade-union-conference-sex-workers-a7944561.html. Accessed 2 February 2018.

17 Siliadin v France (2006) 43 EHRR 16, Rantsev v Cyprus and Russia (2010) 51 EHRR 1.
} 
On the other hand, the emerging labour approach to trafficking focuses on extending all labour protections to all vulnerable workers, including trafficked workers, and it does not view human rights law jurisprudence as the primary means for doing so. As Shamir puts it, the labour approach 'regards trafficking to be an instance of severe labor exploitation that shares characteristics with other forms of worker commodification, which is, to some extent, typical of all employment contracts' (2012, 82). Stopping extreme instance of labour exploitation, including trafficking, therefore requires challenging all troubling labour relations and facilitating backgrounds conditions. Kotiswaran similarly rejects any straightforward juxtaposition of trafficking and free labour, but unlike Shamir argues for a very broad definition of trafficking. Recognising that the means and purpose of trafficking in the UN Trafficking Protocol ${ }^{18}$ 'span a continuum of possibilities', Kotiswaran argues that trafficking is the exploitation of an individual's vulnerability in order to transfer, transport, recruit etc., her into a range of exploitative working conditions, not limited to the most extreme forms $(2014,370)$. For Kotiswaran, then, trafficking itself can cover a spectrum of unacceptable labour relations and facilitating background conditions (see also Chew 2014). Regardless of definitional differences and debates, however, these scholars believe that the anti-trafficking norm and crusade can, and must, be re-oriented towards a labour approach that protects all vulnerable workers.

To this end, uniform minimum measures are proposed, including extension of protective employment laws to all workers, guaranteeing the right of vulnerable workers to organise and eliminating visa regimes that tie workers to a specific employer, safe working conditions and the retention of as much surplus as possible from each worker-client transaction (Kotiswaran 2014, 397-398; Shamir 84). Kotiswaran demonstrates how Indian labour laws regulating intermediaries and employers can provide 'alternate legal imaginaries' that could shape the future direction of a labour response to trafficking $(2014,380)$. These laws make no mention of the 'means' of recruitment, or, along with Article 23 of the Indian Constitution (forced labour), have construed force to cover poverty. As Kotiswaran notes, the key question for the courts has been whether the employer or intermediary exploited the recruited person (390). Employers and intermediaries can be prosecuted or fined, must register with home and host governments, and provide adequate working conditions and a minimum wage. Criminal law, human rights, and 'victim' protections (such as 'rescue' and 'rehabilitation') are then recast as supportive of this primary focus on labour rights and collective organisation.

Shamir and Kotiswaran recognise difficulties with implementation, including the association of trafficking and sex work with sexual exploitation, the strength of the border and crime control responses to trafficking, the weak state of the labour movement globally, and dominant economic interests nationally and internationally. Having identified these interests, Shamir contends that:

\footnotetext{
${ }^{18}$ United Nations Protocol to Prevent, Suppress and Punish Trafficking in Persons, Especially Women and Children, 2000.
} 
the long overdue paradigm shift is not only warranted but also possible. The United States, the European Union, and other countries have already shown a commitment to anti-trafficking and have taken extraordinary steps to combat this problem. Directing this international willingness and these resources into a labor-based program against trafficking would significantly increase the potential for reducing the incidence and severity of trafficking $(2012,83)$.

This agenda certainly sounds promising. But can harnessing existing moral outrage against trafficking effectively challenge the interests blocking a labour approach to trafficking? Is it not the case that the moral outrage and 'extraordinary' steps taken to stop trafficking have occurred largely because anti-trafficking affirms these interests? Anti-trafficking initiatives have been a major investment for nation states and global institutions because they are an effective means for protecting borders and legal markets. This is not a point that needs to be made critically; the actual wording of mandatory obligations in the Protocol evidences it. Moral outrage against trafficking has not led to challenging borders, it has humanised borders and immigration policy (Anderson 2012). Moral outrage against the harms of trafficking has also justified the continued dismissal of decriminalisation and regulation of sex work (Scoular and O'Neill 2007; Munro and Scoular 2013). And can existing moral outrage against trafficking be reoriented to extend rights to highly vulnerable migrant workers when citizen workers less and less enjoy such rights? While initially promising, this labour approach demonstrates an inadequate grasp of national and global capitalist relations of (re)production, which have an interest in border controls, criminalisation of illegal markets including sex work, and the race to the bottom for minimal labour protections for all workers (Ferguson and McNally 2015).

Shamir and Kotiswaran also identify mass mobilisation and collective organisation of workers as essential for the labour paradigm's success. Interested parties, such as NGOs and charities could pressure international organisations and nation states to respond to trafficking with rights for all vulnerable (migrant) workers. However, NGOs, charities, and activists would, for example, need to convince international organisations to take a labour approach to trafficking and this would likely turn into a far reaching policy conversation about what bodies of law and international standards need redefinition. ${ }^{19}$ Could migrant (sex) workers join efforts with citizen workers, NGOs, unions and international organisations to argue for a labour approach to trafficking that would extend rights to all vulnerable workers? Historically it has been through collective mobilisation that rights and protections have been extended to workers, and so this is the most promising route for the labour paradigm. But this raises an obvious question: If the route to achieving a labour approach to anti-trafficking is the extension of basic rights to all vulnerable workers through mass mobilisation, why choose the anti-trafficking norm as the slogan and struggle? Why not 'wage slavery', 'labour unfreedom' or 'freedom'? These norms

\footnotetext{
19 The epic nature of this task cannot be underestimated. It would be desirable for the Protocol to be redrafted to make labour protections mandatory. And whole bodies of law would need to be disarticulated from the trafficking $=$ border control and criminalization rationale, including human rights law.
} 
have a historical legacy and the advantage of speaking to a broad base of workers, both paid and unpaid, migrant and citizen (see O'Connell Davidson 2014b). These norms also have the advantage of being anti-statist and anti-capitalist slogans and so escape the significant degrees of reorientation that anti-trafficking discourse requires to bring it in line with a labour approach, not least its fetishization of sex work and sexual exploitation.

To sum up, then, the danger of de-centring trafficking is that we leave anti-trafficking law and policy in the hands of the state and lose the opportunity to utilise it as a vehicle for challenging labour unfreedom, in migrant sex work and beyond. However, the danger of centring a labour paradigm for trafficking is its profound disconnect from material interests and history. Neither capital nor labour, albeit for different reasons, is likely to provide the mobilisation needed for the success of the labour paradigm in the UK and globally. Rather, it is more likely that it would function as a bureaucratic and policy exercise characterised by unlimited scope and dubious promise and carried out by academics, NGOs, charities, and international organisations. On the other hand, centring struggles for labour 'freedoms'-extending individual and collective labour rights, regulating intermediaries and agents, refusing repressive border controls, expanding social welfare protections to include a basic income and the recognition of care work, and social or affordable housingwill allow migrant sex workers to (continue to) forge connections and solidarity with all other (migrant) workers. The role of NGOs, unions, and international organisations, such as the International Labour Organization would be to promote labour 'freedoms' for paid and unpaid, migrant and citizen workers. To this end, it is possible that the 'decent work' agenda championed by the ILO and Empower, a sex worker organisation in Thailand, could have a role and is not burdened by the weight of 'trafficking' (Vosko 2002; Empower 2016). Trafficking need not disappear in this framework, but it would be relegated to a criminal law response, which is largely in keeping with current policing.

It is very unlikely that the labour approach to anti-trafficking law and policy could help tackle labour unfreedoms in migrant sex work by chipping away at capitalist relations of (re)production. In this moment of unrelenting austerity we face drastically redrawn relations with the EU and a government that is hostile at best towards refugees, asylum seekers, and migrant workers. 'Freedom' in migrant sex work and beyond will be the outcome of the mass mobilisation of workers globally supported by international institutions, such as the ILO, and national law and policy. Given this, we need norms capable of rallying and speaking to all workers. 'Anti-trafficking' is not up to the job. Rather, contesting labour unfreedom and demanding 'freedom' within, and against, capitalist relations of (re)production should be the agenda for migrant sex workers, migrant workers, citizen workers, and all paid and unpaid workers globally. 


\section{Conclusion: Challenging Unfreedom}

In this article, I have used a Marxist feminist methodology to map the organisation of migrant sex workers' socially reproductive paid and unpaid labour in one city and country of arrival, London, UK. I have argued that unfree and 'free' (sexual) labour exists on a continuum of capitalist relations of (re)production, which are gendered, racialised, and legal and that the 'freedom' of the vast majority of migrant sex workers is eclipsed by their unfreedom. This is in stark contrast to the classical liberal claim of sex worker rights activists and academics that the vast majority of migrant sex workers are free, and therefore not coerced, exploited or trafficked. I then considered whether the emerging labour approach to trafficking could help achieve 'freedom' for migrant sex workers and argued that it is highly unlikely. Instead, anti-trafficking must be marginalised in favour of bottom up politicisation of, and struggles against, all forms of labour unfreedom and for 'freedoms'. It is therefore important to end with the reminder that, rather than legal tinkering, all successful efforts for decommodification, for labour 'freedoms' and so control over our labour and lives, have been an outcome of collective struggles within, and against, the state.

Acknowledgements I would like to thank Manuel Cruz, Althea Lazzaro, Julia O'Connell Davidson, Yvette Russell, Jane Scoular, Kathi Weeks, Xanthe Whittaker, Ann Blair, colleagues at the University of Leeds and Bristol who generously engaged with this paper during research seminar sessions, and comrades with whom I have debated these issues. I am particularly grateful for the anonymous reviews that I received, which pushed me to clarify my convictions and analysis. All errors are my own.

Open Access This article is distributed under the terms of the Creative Commons Attribution 4.0 International License (http://creativecommons.org/licenses/by/4.0/), which permits unrestricted use, distribution, and reproduction in any medium, provided you give appropriate credit to the original author(s) and the source, provide a link to the Creative Commons license, and indicate if changes were made.

\section{References}

Agustín, Laura. 2007. Sex at the Margins: Migration, Labour Markets and the Rescue Industry. London: Zed Books.

Adams, Niki. 2003. Anti-Trafficking Legislation: Protection or Deportation? Feminist Review 73: $135-139$.

Agustín, Laura. 2006. The Disappearing of a Migration Category: Migrants Who Sell Sex. Journal of Ethnic and Migration Studies 32: 29-47.

Anderson, Bridget. 2010. Migration, Immigration Controls and the Fashioning of Precarious Workers. Work, Employment \& Society 24: 300-317.

Anderson, Bridget. 2012. Where's the Harm in That? Immigration Enforcement, Trafficking, and the Protection of Migrants' Rights. American Behavioral Scientist 56: 1241-1257.

Association of Chief Police Officers (ACPO). 2010. 'The trafficking of migrant women in the England and Wales off-street prostitution sector'. http://www.uknswp.org/wp-content/uploads/Setting\%20the \%20Record\%20(Project\%20ACUMEN)\%20Aug\%202010\%5B1\%5D.pdf. Accessed 2 Feb 2018.

Baehr, Amy. 2017. A Capacious Account of Liberal Feminism. Feminist Philosophy Quarterly 3. http:// ir.lib.uwo.ca/fpq/vol3/iss1/4/. Accessed 2 Feb 2018.

Banaji, Jairus. 2003. The Fictions of Free Labour: Contract, Coercion, and So-Called Unfree Labour. Historical Materialism 11: 69-95.

Barry, Kathleen. 1995. The Prostitution of Sexuality: The Global Exploitation of Women. New York: New York University Press. 
Bernstein, Elizabeth. 2007. Temporarily Yours: Intimacy, Authenticity, and the Commerce of Sex. Chicago: University of Chicago Press.

Bernstein, Elizabeth. 2010. Militarized Humanitarianism Meets Carceral Feminism: The Politics of Sex, Rights, and Freedom in Contemporary Anti-trafficking Campaigns. Signs: Journal of Women in Culture and Society 36: 45-71.

Bindman, Jo and Jo Doezema. 1997. Redefining Prostitution as Sex Work on the International Agenda. https://www.atria.nl/epublications/1997/Redefining_Prostitution.pdf. Accessed 2 Feb 2018.

Brass, Tom. 1994. Some Observations on Unfree Labour, Capitalist Restructuring, and Deproletarianization. International Review of Social History 39: 255-275.

Bryson, Valerie. 2005. Production and Reproduction. In Marx and Other Four Letter Words, ed. Georgina Blakeley and Valerie Bryson, 127-142. London: Pluto Press.

Busby, Nicole. 2014. Unpaid Care, Paid Work and Austerity: A Research Note. Feminists@law 14. http:// journals.kent.ac.uk/index.php/feministsatlaw/article/view/100/259. Accessed 2 Feb 2018.

Cavalieri, Shelley. 2011. Between Victim and Agent: A Third-Way Feminist Account of Trafficking for Sex Work. Indiana Law Journal 86: 1408-1458.

Chew, Janie. 2014. Exploitation Creep and the Unmaking of Human Rights Law. The American Journal of International law 1: 609-649.

Clough, Beverley. 2015. Vulnerability and Capacity to Consent to Sex-Asking the Right Questions? Child and Family Law Quarterly 26: 371-397.

Conaghan, Joanne. 2017. Gender and the Labour of Law. In Philosophical Foundations of Labour Law, (eds) Hugh Collins, Gillian Lester and Virginia Mantouvalou. Forthcoming.

Crown Prosecution Service. 2011. Human Trafficking. HM Government: Smuggling and Slavery.

Cruz, Katie. 2013. Unmanageable Work, (Un)liveable Lives: The UK Sex Industry, Labour Rights and the Welfare State. Social Legal Studies 22: 465-488.

Cruz, Katie, Kate Hardy, and Teela Sanders. 2017. False Self-Employment, Autonomy, and Regulating for Decent Work: Improving Working Conditions in the UK Stripping Industry. British Journal of Industrial Relations 55: 274-294.

Dempsey, Michelle. 2010. Sex Trafficking and Criminalization. In Defense of Feminist Abolitionism. University of Pennsylvania Law Review 158: 1729-1778.

Dempsey, Michelle, et al. 2012. Defining Sex Trafficking in International and National Law: Mind the Gaps. Emory International Law Review 26: 137-162.

Denning, Michael. 2010. Wageless Life. New Left Review 66: 79-97.

Dickenson, Donna. 1997. Property, Women and Politics. Oxford: Polity.

Ditmore, Melissa. 2008. Sex Work vs. Trafficking: Understanding the Difference. http://www.alternet.org/ story/84987/sex_work_vs._trafficking\%3A_understanding_the_difference. Accessed 2 Feb 2018.

Doezema, Jo. 2005. Now You See Her, Now You Don't: Sex Workers at the UN Trafficking Protocol Negotiation. Social and Legal Studies 14: 61-89.

Empower. 2016. Moving toward decent work. Empower University Press. http://www.nswp.org/sites/ nswp.org/files/Moving\%20Toward\%20Decent\%20Work\%2C\%20EMPOWER\%20-\%20April\%20 2016.pdf. Accessed 2 Feb 2018.

Farris, Sara. 2015. Social Reproduction, Surplus Populations and the Role of Migrant Women. Viewpoint Magazine. https://www.viewpointmag.com/2015/11/01/social-reproduction-and-surplus-population s/. Accessed 2 Feb 2018.

Federici, Silvia. 2011. Feminism and the politics of the commons. The Commoner. http://www.commo ner.org.uk/wp-content/uploads/2011/01/federici-feminism-and-the-politics-of-commons.pdf Accessed 2 Feb 2018.

Ferguson, Sue. 2008. Canadian Contributions to Social Reproduction Feminism, Race and Embodied Labor. Race, Gender \& Class 15: 42-57.

Ferguson, Sue, and David McNally. 2015. Precarious Migrants: Gender, Race and the Social Reproduction of a Global Working Class. In Transforming Classes: Socialist Register 2015, ed. Leo Panitch and Greg Albo, 1-23. London: Merlin Press.

Ferguson, Sue. 2016. Intersectionality and Social-Reproduction Feminisms Toward an Integrative Ontology. Historical Materialism 24: 38-60.

Foster, John Bellamy. 2010. The Financialization of Accumulation. Monthly Review: An Independent Socialist Magazine. https://monthlyreview.org/2010/10/01/the-financialization-of-accumulation/. Accessed 2 Feb 2018.

Fudge, Judy, and Rosemary Owens (eds.). 2006. Precarious Work, Women, and the New Economy: The Challenge to Legal Norms. Portland: Hart Publishing. 
Fudge, Judy. 2013. Precarious Migrant Status and Precarious Employment: The Paradox of International Rights for Migrant Workers. Comparative Labor Law \& Policy Journal 34: 95-132.

Gallagher, Anne. 2009. Human Rights and Human Trafficking: Quagmire or Firm Ground? A Response to James Hathaway. Virginia Journal of International Law 49: 789-848.

Gira Grant, Melissa. 2014. Playing the Whore: The Work of Sex Work. London: Verso.

Global Alliance Against Trafficking in Women. 2010. Beyond Borders: Exploring the link between trafficking and migration. Working paper series 2010. http://www.gaatw.org/publications/WP_ on_Migration.pdf. Accessed 2 Feb 2018.

Gough, Ian. 1972. Marx's Theory of Productive and Unproductive Labour. New Left Review 76: 47-72.

Halley, Janet, et al. 2006. From the International to the Local in Feminist Legal Responses to Rape, Prostitution/Sex Work, and Sex Trafficking: Four Studies in Contemporary Governance Feminism. Harvard Journal of Law \& Gender 29: 335-423.

Hardy, Kate, and Teela Sanders. 2012. Devalued, Deskilled and Diversified: Explaining the Proliferation of the Strip Industry in the UK. The British Journal of Sociology 63: 513-532.

Hardy, Kate, and Teela Sanders. 2014. Flexible Workers: Labour, Regulation and the Political Economy of the Stripping Industry. London: Routledge.

Hardy, Kate, and Teela Sanders. 2015. The Political Economy of 'Lap Dancing': Contested Careers and Women's Work in the Stripping Industry. Work, Employment \& Society 29: 119-136.

Hardy, Kate. 2016. Uneven Divestment of the State: Social Reproduction and Sex Work in Neo-developmentalist Argentina. Globalizations 6: 876-889.

Harvey, David. 2011. The Enigma of Capital: And the Crises of Capitalism. London: Profile Books.

Hill, Angela. 2011. "This Modern Day Slavery": Sex Trafficking and Moral Panic in the United Kingdom. PhD thesis, University of California Berkeley.

Holmstrom, Nancy. 1977. Exploitation. Canadian Journal of Philosophy 7: 353-369.

Hoyle, Carolyn, et al. 2011. Labelling the Victims of Sex Trafficking: Exploring the Borderland between Rhetoric and Reality. Social and Legal Studies 20: 313-329.

Jeffreys, Sheila. 2009. The Industrial Vagina: The Political Economy of the Global Sex Trade. Abingdon: Routledge.

Kotiswaran, Prabha. 2014. Beyond Sexual Humanitarianism: A Postcolonial Approach to Anti-Trafficking Law. UC Irvine Law Review 4: 353-405.

Larson, Jane. 2004. Prostitution, Labor and Human Rights. U.C Davis Law Review 37: 673-700.

LeBaron, Genevieve. 2015. Unfree Labour Beyond Binaries: Insecurity, Social Hierarchy and Labour Market Restructuring. International Feminist Journal of Politics 17: 1-19.

Lewis, Hannah, et al. 2014. Hyper-precarious lives: Migrants, work and forced labour in the Global North. Progress in Human Geography 39: 580-600.

Mackenzie, Catriona. 2014. The Importance of Relational Autonomy and Capabilities for an Ethics of Vulnerability. In Vulnerability: New Essays in Ethics and Feminist Philosophy, ed. Catriona Mackenzie, Wendy Rogers, and Susan Dodds, 33-59. Oxford: Oxford University Press.

MacKinnon, Catharine. 1989. Towards a Feminist Theory of the State. Cambridge: Harvard University Press.

MacKinnon, Catharine. 2010. Engaged Scholarship as Method \& Vocation. Yale Journal of Law \& Feminism 22: 193-205.

MacKinnon, Catharine. 2011. Trafficking, Prostitution, and Inequality. Harvard Civil Rights-Civil Liberties Law Review 46: 271-309.

Mai, Nick. 2009. Migrant Sex Workers in the UK Sex Industry: Final Policy Relevant Report. Swindon: ESRC.

Mantouvalou, Virginia. 2010. Modern Slavery: The UK Response. Industrial Law Journal. 39: $425-431$.

Marx, Karl. 1990. Capital: Volume 1. London: Penguin books (first published 1867).

Marx, Karl. 1977. Theories of Surplus Value. In Karl Marx: Selected Writings, ed. David McLellan, 393-414. Oxford: Oxford University Press.

Marx, Karl, and Friedrich Engels. 1968. The German Ideology. https://www.marxists.org/archive/ marx/works/download/Marx_The_German_Ideology.pdf. Accessed 2 Feb 2018.

McGrath, Siobhán, and Kendra Strauss. 2015. Unfreedom and Workers' Power: Ever-present Possibilities. In The International Political Economy of Production, ed. Kees van der Pij1, 299-317. Cheltenham: Edward Elgar. 
Mezzadri, Alessandra. 2016. Modern Slavery and the Gendered Paradoxes of Labour Unfreedom. Open Democracy, 26 July.

Meiksins Wood, Ellen. 2000. Democracy Against Capitalism: Rethinking Historical Materialism. Cambridge: Cambridge University Press.

Milivojevic, Sanja, and Sharon Pickering. 2013. Trafficking in People, 20 Years On: Sex, Migration and Crime in the Global Anti-Trafficking Discourse and the Rise of the Global Trafficking Complex. Current Issues in Criminal Justice 25: 585-604.

Mollo, Maria de Lourdes R., and Alfredo Saad-Filho. 2002. Inflation and Stabilization in Brazil: A Political Economy Analysis. Review of Radical Political Economics 34: 109-135.

Munro, Vanessa. 2005. A Tale of Two Servitudes: Defining and Implementing a Domestic Response to Trafficking of Women for Prostitution in the UK and Australia. Social and Legal Studies 14: 91-114.

Munro, Vanessa, and Jane Scoular. 2013. Harm, Vulnerability, and Citizenship: Constitutional Concerns in the Criminalization of Contemporary Sex Work. In The Constitution of the Criminal Law, ed. R.A. Duff, et al., 30-52. Oxford: Oxford University Press.

Murray, Kristen. 2001. Sex work as work: labour regulation in the legal sex industry in Australia. Masters Thesis: University of Melbourne, Australia.

Network of Sex Work Projects. 2011. Sex Work is Not Trafficking. http://www.nswp.org/sites/nswp. org/files/SW\%20is\%20Not\%20Trafficking.pdf Accessed 2 Feb 2018.

Nussbaum, Martha. 1998. "Whether from Reason or Prejudice": Taking Money for Bodily Services. The Journal of Legal Studies XXVII: 693-724.

O'Connell Davidson, Julia. 1998. Prostitution, Power and Freedom. Ann Arbor: University of Michigan Press.

O'Connell Davidson, Julia. 2006. Will the Real Sex Slave Please Stand Up. Feminist Review 83: 4-22.

O'Connell Davidson, Julia. 2009. A Question of Consent? Sexual Slavery and Sex Work in the UK. Working Paper, Identity, Citizenship and Migration Centre, University of Nottingham, Nottingham.

O'Connell Davidson, Julia. 2010. New Slavery, Old Binaries: Human Trafficking and the Borders of 'Freedom', Global Networks 10: 244-261.

O'Connell Davidson, Julia. 2014a. Prostitution and Trafficking for Sexual Labour. In The Routledge Handbook of Global Ethics, ed. Darrel Moellendorf and Heather Widdows, 279-291.

O'Connell Davidson, Julia. 2014b. Let's Go Outside: Bodies, Prostitutes, Slaves and Worker Citizens. Citizenship Studies 18: 516-532.

O'Connell Davidson, Julia. 2015. Modern Slavery: The Margins of Freedom. Basingstoke: Palgrave Macmillan.

Phillips, Nicola. 2013. Unfree Labour and Adverse Incorporation in the Global Economy: Comparative Perspetives on Brazil and India. Economy and Society 42: 171-196.

Raymond, Janice. 2004. Prostitution on Demand: Legalizing the Buyers as Sexual Consumers. Violence Against Women 10: 1156-1186.

Scoular, Jane and Maggie O’Neill. 2007. Legal Incursions into Supply/Demand: Criminalising and Responsibilising the Buyers and Sellers of Sex in the UK. In Demanding Sex: Critical Reflections on the Regulation of Prostitution, ed. Vanessa E Munro and Maria Della Giusta, 13-33. Aldershot: Ashgate.

Shamir, Hila. 2012. A Labor Paradigm for Human Trafficking. UCLA Law Review 60: 76-136.

Strauss, Kendra. 2012. Coerced, Forced and Unfree Labour: Geographies of Exploitation in Contemporary Labour Markets. Geography Compass 6: 137-148.

Strauss, Kendra, and Judy Fudge. 2013. Temporary Work, Agencies and Unfree Labour: Insecurity in the New World of Work. In Temporary Work, Agencies and Unfree Labour: Insecurity in the New World of Work, ed. Judy Fudge and Kendra Strauss, 1-25. London: Routledge.

Strauss, Kendra, and Siobhán McGrath. 2016. Temporary Migration, Precarious Employment and Unfree Labour Relations: Exploring the 'Continuum of Exploitation' in Canada's Foreign Worker Program. Geoforum 78: 199-208.

SWAN. 2015. Im/migrant Sex Workers, Myths and Misconceptions: Realities of the Anti-Trafficked. http://swanvancouver.ca/wp-content/uploads/2014/01/Realities-of-the-Anti-Trafficked.pdf. Accessed 2 Feb 2018.

The x:talk project. 2010. Human Rights, Sex Work and the Challenge of Trafficking. London: Creative Commons. 
Tregenna, Fiona. 2011. What Does the 'Service Sector' Mean in Marxian Terms? Review of Political Economy 23: 281-298.

Vosko, Leah F. 2002. 'Decent Work' The Shifting Role of the ILO and the Struggle for Global Social Justice. Global Social Policy 2: 19-46.

Weeks, Kathi. 2004. 'Labor, Standpoints, and Feminist Subjects' In The Feminist Standpoint Theory Reader: Intellectual and Political Controversies, ed. Sandra Harding 181-194. London: Routledge.

Weeks, Kathi. 2007. Life Within and Against Work: Affective Labor, Feminist Critique, and Post-Fordist Politics. Ephemera Theory and Politics in Organization 7: 233-249.

Weeks, Kathi. 2011. The Problem with Work: Feminism, Marxism, Antiwork Politics, and Postwork Imaginaries. Durham: Duke University Press. 